\title{
Chapter 5 \\ What Makes Turkey and Turkish \\ Immigrants a Cultural Polarization Issue \\ in Europe? Evidence from European \\ Right-Wing Populist Politics
}

\author{
Gokay Özerim and Selcen Öner
}

\subsection{Introduction}

Turkey first expressed its intention to become a member of the European Union (EU) in 1959 by applying to the European Economic Community. Subsequently, it signed the Association Agreement with the EU in 1963, applied for full membership in 1987, and completed the Customs Union process in 1996. It was officially recognized as a candidate country for EU membership at the Helsinki Summit of 1999, and the membership negotiations were initiated in 2005. In spite of Turkey's long history of candidacy to EU membership, intense trade relations with European countries, and the presence of Turks as one of the largest minority ethnic groups in Europe, Turkey and Turkish immigrants have still been instrumentalized as politically polarizing issues in European societies. Turkish immigration to European countries continued to increase even after the shocks of the Oil Crisis in the 1970s, in particular, through family reunification. However, while trade and economic relations have intensified, culture and identity issues remain a challenge in EU-Turkey relations. The recent financial and "refugee (reception) crisis" that the European continent witnessed have deepened these challenges. Consequently, Turkish presence in Europe, compatibility of Turkish identity to European identity, Turkey's "Europeanness" and EU membership process have been re-questioned by some actors, mostly by the ones that aim to revitalize the nostalgia of "pure Europeanness" by scapegoating "others" through exploiting economic, social, and cultural anxieties.

\footnotetext{
G. Özerim ( $\bowtie)$

Department of International Relations, Yaşar University, Izmir, Turkey

e-mail: gokay.ozerim@yasar.edu.tr

S. Öner

Department of Political Science and International Relations, Bahçeşehir University, Istanbul, Turkey

e-mail: selcen.oner@eas.bau.edu.tr
} 
In this regard, the interplay between politics of culture, welfare, and migration, which are the key focus of the present volume, were employed in the discourse of the populist actors in Europe as a tool for framing and excluding Turkish immigrants and Turkey. On the one hand, as Neumann (1998) underlines, the "otherness" of Turks has been an identifying element of Europeanness for long. On the other hand, Turkey has long been perceived as a "bridge country", particularly in the 2000s and after Turkey was given an official candidate status. Turkey has been framed as an important neighbor and a crucial partner for the EU (Öner 2011). However, the "otherness" was brought again onto the political agenda of several European countries by the latest series of crises.

This chapter provides a comparative analysis of this instrumentalization process in European politics by asking how Turkish immigrants and Turkey are presented as a culturally polarizing issue within the framework of "cultural security" (Guild 2005; Tardif 2002). It addresses cultural elements of "Turco-skeptic" policies in European right-wing populist parties' discourse. A descriptive analysis based on three specific cases is performed, and its findings lend support to our claims about the existence of anxieties due to cultural security concerns in European right-wing policies, and helps us identify the cultural elements within these policies. The material selection, which the descriptive analysis is built on, is more ad-hoc based than systematically conducted. However, the emphasis is put on the speeches of the leading political actors within the related political processes and campaigns, campaign posters and party broadcasts in the conventional media are used as the resources for materials. The selected cases are assessed within a historical framework, also by referring to the previous discourses and policies of the major political actors in each of them. The first case is the Brexit referendum process in the United Kingdom (UK), specifically the Vote Leave campaign. The second case is the instrumentalization of Turkish immigrants and Turkey's accession to the EU in Austrian domestic politics particularly after the "refugee (reception) crisis" and during the campaign for the 2016 Austrian Presidential elections. The third case is the instrumentalization of Turkish immigrants and Turkey's accession to the EU in German politics, particularly the rise of Alternative for Germany (Alternative für Deutschland, AfD), and its entrance into German federal parliament in the aftermath of 2017 elections.

These cases are analyzed within the framework of the nexus between Turks in Europe and European cultural cleavages. This is done by focusing on what sort of cultural arguments regarding Turkey appear in political discourses, the underlying cultural elements of these actors' discourse on Turkish immigrants, and the culturalhistorical reasons for the success of these discourses in each selected case, and their crucial influence on the domestic politics of various European countries. Meanwhile, the "cultural security" theme is presented as the theoretical background of the study. 


\subsection{Cultural Security as an Instrument of Right-Wing Populism}

Against this background, seeking the traces of cultural security in the Turco-skeptic discourse of European right-wing populist parties may provide valuable insights on the instrumentalization of Turkish migrants for the sake of voter mobilization. "Cultural security" can be defined as the "protection of original values (such as tradition, language, religion, customs, etc.) and characteristics of a society against existing conditions and potential threats" (Tardif 2002). Guild investigates the use and influence of culture as a security theme by asking this important question: "What is the link between culture and identity in terms of 'nationality' and 'sovereignty'?" (Guild 2005, p.101). Building on this, one can also ask whether culture and identity are the tools, or symbols of national sovereignty. The answer to these questions also plays a decisive role in the framing of immigrants in contemporary European host societies. From a cultural point of view, the answer to this question by right-wing populist parties seems to be "yes, absolutely". More importantly, these parties limit the notion of culture to the "indigenous" citizens of their country and classify it as an "entity" that has already reached its highest point, which consequently need not be enlarged or expanded anymore (see, Cinpoeş and Norocel, Chap. 4; Hellström and Tawat, Chap. 2 in this volume). This protectionist perception of culture frames migrants as a threat to cultural security.

For many right-wing populist parties, the "native" citizens of a country are accepted as the sole originators, and rightful owners of the country's culture. Accordingly, culture must have a specific definition, and it should be isolated from "foreign" elements. This perception directly plays to the "cultural security" theme and frames migrants as a threat to the host country's "local culture", and the lifestyle of "native" citizens. In this respect, the anti-immigration discourse of these parties promotes the idea that migrant populations will in time destroy the homogeneous and unique structure of national culture. In response, right-wing populist parties advocate for restrictive regulations against migration, and demonize those policies promoting multiculturalism and the integration of migrants (Williams 2006, p. 70). They do not only defend the national culture of the host country. Rather, they also refer to European culture when claiming the necessity of protecting it from the "raid of foreigners" and waves of globalization (Betz 2001, p. 394). Based on these exclusivist and identity-based policies, they fuse the concepts of non-citizens and "others" (Kaya 2009, p. 9).

Berezin defines modern nation-states as a marriage of culture and structure, which resembles a two-atom molecule, bounded by "territorial consolidation" on the one hand, and "cultural consolidation" on the other (Berezin 2009, pp. 53-54). In light of Berezin's example, the issue of cultural security can also be considered the definition of the state in Weberian terms. According to Weber, the political community is a phenomenon that is shaped around ethnic pride, feelings of similarity, and common group beliefs stemming from the same culture and solidarity (Berezin 2009 , p. 52). This definition necessitates "cultural consolidation" as a core value of 
the modern state. The discourse based on "cultural security", which mostly addresses these "core values", may find a stronger public response than one might expect. Anti-immigration discourses drawing on cultural security concerns do not manifest themselves only in calls to reduce, or halt migration. They also aim to shape the policies and practices of integration for those who have already immigrated. However, the efforts of right-wing populist parties stem from the ambition to protect the national language as a critical element of culture rather than from a desire to support the integration of immigrants.

Eventually, the distinction between "us" and "them" creates symbolic boundaries in addition to existing boundaries. There can be symbolic boundaries within social identity, as well as physical boundaries between countries, and in fact, these boundaries are created using a set of sub-themes, such as religion and language (Bail 2008). Apart from this, liberal values such as LGBT rights, equality between women and men, and other freedoms are also regarded as part of European culture, and immigrants are portrayed as a threat to these values (Hellström 2016; Norocel 2017). Accordingly, these values must be protected. This discourse of right-wing populist parties is framed alongside religious differences, and as a result, "othering by religion" is an important element of cultural security discourse. Consequently, Islamophobia comprises a significant component of anti-immigration sentiment and "nativism" in Europe, which also makes it a tool of populist discourse. From this point of view, anti-Islamism functions as a significant mobilizer for right-wing populist party voters.

\subsection{The Turkish Community in Europe and Cultural Cleavages}

Turkish immigrants and co-ethnic Turks in Europe constitute one of the major elements of the relationship between Turkey and Europe. After the end of World War II, Turkish immigrants provided an essential labor contribution to the reconstruction of European economies. The Turkish government signed bilateral recruitment agreements with Germany in 1961, the Netherlands, Austria, and Belgium in 1964, France in 1965, and with Sweden in 1967. These bilateral agreements, which were initially framed as temporary "guest worker" schemes, unexpectedly resulted in many permanent stays. Consequently, nearly 800,000 Turks became citizens in the host country in which they worked, and Turkish immigrants and their families became "the largest group of non-nationals resident in the EU" (İçduygu 2011, p. 9). Even as European countries were focusing on more restrictive immigration policies following the Oil Crisis of 1973, family reunification allowed for continued Turkish migration into Europe. In addition to labor migration, the conflicts of the 1970s and the 1980 military coup in Turkey added increasing numbers of Turkish asylum seekers to the picture (Sirkeci and Esipova 2013, p. 3). As a result, around 5.5 million Turks live in West European countries, mainly in Germany, the 
Netherlands, France, Switzerland and Austria (Turkish Ministry of Foreign Affairs 2018).

In the meantime, "Turco-skepticism" has become a political card for the new wave of right-wing populism in Europe. Some researchers argue that, for a number of reasons Turkey has become a flash point for the rising xenophobic movements in Europe after the 2000s. One of the most prominent reasons seems to be the "existence of a large cohort of Turkish population" in Europe (Kirişçi 2003, p. 79). Right-wing populist parties using neo-nationalist and anti-immigrant discourse are on the rise in almost all the European countries, which have received Turkish immigrants as part of guest worker schemes in the 1960s and 1970s. The existence of Turkish immigrant communities in European countries, and particularly their integration problems are generally considered as one of the main reasons for the development of Turco-skepticism in Europe (European Commission 2016, p. 3).

However, it should be noted that the Turkish community in Europe originated primarily from economic immigration rather than asylum seeking. As a result, the "economic burden" and "welfare" based anti-immigrant discourse used by European right-wing populist parties does not have a strong base, as Turkish immigrants actually contributed positively to the economies of many of European host societies. In fact, the Central and Eastern enlargements of the EU invalidate the economic arguments against Turkey's EU membership, due to the relatively poor economic conditions of these countries at the time they gained membership (Bozdaglioglu 2004, p. 93). As a result, culture and identity-based arguments have become important for Turkey's EU accession process, and for the presence of Turkish communities across Europe. Therefore, contrary to general wisdom, major themes of European Turcoskeptic rhetoric rely not on economic anxieties but on cultural cleavages that are fueled by a wide spectrum of arguments. Although religious differences are one of the factors underlying these cultural arguments, the instrumentalization of Turkish immigrants by right-wing populist parties is not limited to this subtheme. It also draws on a fear of threats to the liberal values of Europe, democracy and the lifestyle of European countries.

These cultural cleavages overshadow even economic anxieties and have become an agenda item in the contemporary political debates of European countries. This effect is not limited to countries with a high number of immigrants of Turkish origin, such as Germany and Austria. Similar debates were observed in the UK during the Brexit referendum campaign, despite the fact that the UK has fewer Turkish immigrants and has had a relatively positive stance towards Turkey's EU membership for many years. Turkey's potential EU membership appears to be one of the most prominent sources of identity and culture-based opposition to Turks (Yilmaz 2007, p. 293). It is worthwhile to note that while opposition to Turkey's EU membership has many sociological, geographical, historical, and political grounds in Europe, the debates on the triangle of culture, religion, and identity are remarkably fraught even in the countries that have been hosting large numbers of Turkish immigrants for decades. However, the history of contact between Turks and Europeans is not limited to post World War II labor migration and EU accession process. That 
history extends to the previous relations with the Ottoman Empire, whereby Turks were framed as the "other" in European imagery (Bozdaglioglu 2004, p. 93).

\subsubsection{Case 1: Vote Leave "Playing the Turkish Card" for Brexit}

Turkish migration to the UK began in the late 1960s and continued during the early 1970s due to labor migration. Following the war in Cyprus in 1974, TurkishCypriots began to immigrate in significant numbers and the population of Turkishborn immigrants in the UK increased (Küçükcan 1999, p. 61). After the 1980 military intervention in Turkey, the UK became one of the main destinations for Turkish asylum seekers, in addition to a continued inflow of economic migrants. According to the statistics (Office for National Statistics 2017), there were around 73,000 Turks in the UK. In terms of population density, Turks are not among the top five countries with the largest "overseas born population resident in the UK". However, Turkey and Turkish identity constituted one of the hot-button points in the Vote Leave Campaign of the June 2016 referendum.

The hostile rhetoric used throughout the campaign centered primarily on Turkey's possible EU membership by asking voters whether they want to be in an EU that includes Turkey. The question was imbibed with fear mongering and misinformation. For example, the Vote Leave block released a campaign poster bearing only the line, "Turkey (population 76 million) is joining the EU". The implication was that Turkey's accession would lead to mass migration to the UK and might result in increased security challenges in the EU. One of the prominent figures of the Vote Leave campaign, Penny Mordaunt, former British Armed Forces Minister, and recently Minister of State at the Department for Work and Pensions, claimed that Britain would be "unable to stop Turkey joining the EU". She claimed, "a million Turks could potentially come to the UK within eight years of joining, a scale of migration that would run the risk of enabling murderers, terrorists, and kidnappers to enter the country" (BBC 2016). Former UK Independence Party (UKIP) leader Nigel Farage, another important figure of the Leave Campaign, supported this discourse, stating, "the referendum is very quickly becoming a vote on whether we want to be in a political union with Turkey, which would open our borders to millions of Turks with all the security risks that would bring" (Wheeler and Giannangeli 2016).

UKIP also released a broadcast titled "The risks of staying in the EU: No. 1Turkey joins in 2020?" The video claims that "as many as 15 million migrants could leave for Europe within the first 10 years of EU membership". The video includes arguments emphasizing that only $3 \%$ of Turkish landmass is in Europe, while the rest is in Asia, and that a possible EU membership would make Turkey the most populous country in the EU, thereby allowing it supreme power in the EU institutions and decision-making. Finally, it asserts that with Turkey's membership, the 
EU would become a neighbor to Iraq, Iran, and Syria. In fact, these are all wellknown and popular arguments of opponents to Turkey's EU membership (MüftülerBac 1998; Gerhards and Hans 2011). However, the broadcast also addresses freedom of press, women's rights, the fact that rates of violence against women in Turkey are above the European average, the prevalence of marriage at an early age, and the decline of the Christian population in the country. In particular, a strong emphasis on Islam and the Muslim majority in Turkey was present prominently in UKIP's Vote Leave Campaign. The mainstream media accused the party of "baseless scaremongering" many times during the Brexit campaign, as its discourse promoted a disguised but deeply rooted Islamophobia (Mason 2016).

Liberal values and freedoms were framed as part of European and British culture, as frequently seen throughout populist discourse that use the "cultural security" theme. However, in the case of the Vote Leave campaigns, the idea of a "high level of criminality among Turkish citizens" was integrated into this theme. Instead of using only cultural themes, terrorism and crime were embedded into the discourse, which presented Turkey and Turkish immigrants as a threat to national security (Boffey and Helm 2016). The cultural security-based campaign of Vote Leave was noted in the British media. The Independent, a popular daily newspaper in the UK, published an article titled "Vote Leave: Stop offending Turkish people to further your own agenda". The piece criticized another popular daily newspaper, the Express, for intentionally using the image "of a woman in a burqa fashioned from the EU flag" while reporting on a survey, which claimed that Turkey's EU membership would encourage a third of Britons to vote for leaving the EU (Wheeler and Giannangeli 2016).

In addition, part of the Vote Leave campaign discourse presented Turkey as part of a possible Balkan enlargement. It was claimed "a vote of stay would allow people from Albania, Macedonia, Montenegro, Serbia, and Turkey to immigrate to UK freely when they join the EU soon" (Lister 2016). As such, the theme of cultural security morphed into a matter of "internal security" (Mandac1 and Özerim 2013). Such a stance was built on misinformation or manufactured information, since the UK was not even within the Schengen area agreement, which makes a rapid and an uncontrolled mass migration from any of these potential new EU member countries almost impossible.

UKIP also shared videos of David Cameron, who had previously defended Turkey's EU membership bid. However, Cameron's stance in favor of Turkey's EU membership was keeping with the traditional stance of the British government, which has been one of the strongest advocates for membership for many years. Regardless, right-wing populist rhetoric instrumentalized Turks and Turkish identity in order to disseminate fear, mobilize voters, and strengthen its anti-establishment stance against traditional British politics. Moreover, Boris Johnson, who had targeted Turkey's potential EU membership during the Vote Leave campaigns, declared in the aftermath of the Brexit referendum that he would support Turkey's EU bid. This is but an example of the hypocrisy of right-wing populist politicians, who instrumentalized certain issues for short-term purposes. 


\subsubsection{Case 2: Instrumentalization of Turkey and Turkish Immigrants in Austrian Politics}

Since the beginning of the twentieth century, assimilation has been the major strategy for cultural and linguistic minorities in Austria. These groups, including Turkish immigrants, remain marginalized and segregated, and even the third-generations tend to have higher unemployment rates, lower wages, and less educational success than Austrians on average. Moreover, the rise of right-wing populism in Austria has influenced negatively immigration policies (Wets 2006, pp. 92-93).

The main narrative about Turkey in Austria is a typical example of a cultural "other". The Ottoman sieges of Vienna in 1529 and 1683 are two crucial events that are reported in Austrian history textbooks (Gavenda 2017). These historical references about Ottoman Empire have been used frequently in Austrian domestic politics. Another crucial theme is immigration, especially with regards to Turkey-EU relations. In the early 1960s, more workers were required to meet the demands of a growing economy. From the beginning of 1960s until the mid-1970s, guest workers were recruited mainly from Turkey and former Yugoslavia. The bilateral agreement between Turkey and Austria regulating short-term immigration of Turkish workers was signed in 1964. By the early 1970s it became clear that the Turkish community's presence had become permanent. Indeed, the largest groups of non-EU foreigners in Austria are the nationals from the former Yugoslavia and Turkey. Turks are often represented as the least integrated group of immigrants (Wets 2006, pp. 85-89). In 2017, it was estimated that the number of Austrian residents of Turkish origin was of around 260,000 (Gavenda 2017).

Even previously, there were particularly high levels of skepticism about Turkey's EU membership, especially in Austria and Germany, where there are large numbers of Turkish immigrants. Before the financial crisis and the Brexit referendum, Turkey's EU membership had been used frequently for domestic political gains before the elections, especially by right-wing populist parties, as well as by mainstream parties, such as the Christian Democrats (Yabanc1 2016). The survival of a European culture against the threat posed by the "Muslim other" is a recurring theme in right-wing populist rhetoric (Ajanovic et al. 2016, p. 143).

More recently, Austria opposed a revitalization of membership talks between Turkey and the EU and even called for their suspension. In November 2016, all six parties from the federal parliament issued a joint statement that condemned the human rights situation in Turkey and called on the EU to suspend the negotiations. Former foreign minister, currently the Chancellor Sebastian Kurz demanded a freeze to accession negotiations at the EU Council meeting, though this call was not supported by the foreign ministers of most of the other member states (Gavenda 2017).

As a distinctive example, the right-wing populist party "Freedom Party of Austria" (Freiheitliche Partei Österreichs, FPÖ) claims that the living standards for Austrian citizens are in need of protection, and that immigrants who are unwilling to integrate should be forced to leave the country (Dennison and Pardijs 2016, p. 7). But this stance has a longer history. Already in the 2005 campaign for the municipal 
elections in Vienna, the FPÖ electoral slogan was "Vienna must not become Istanbul" (Gavenda 2017). In recent decades, the FPÖ pioneered many rhetorical strategies of populist movements across Europe and also played a "key role in casting Islam as an existential threat to European identity and values", which has crucially influenced its German counterpart, the Alternative for Germany (Alternative für Deutschland, AfD) (Politico 2016). "Catholic Austria, which fought back two Ottoman sieges during the Hapsburg Empire, was again under assault" FPÖ claimed in response to the refugee (reception) crisis, and the terrorist threats facing Europe in the last few years (Politico 2016).

In the aftermath of the refugee (reception) crisis, FPÖ positioned itself as a protector of Austria's heritage and borders against the influx of immigrants. FPÖ sees a lack of solidarity and unity between EU Member States as the main cause of the series of crisis (financial, Euro-zone, and humanitarian) that have recently shaken the EU. Moreover, FPÖ perceives the "refugee deal" between Turkey and the EU as a disaster since it is against any alignment of the EU with Turkey (Dennison and Pardijs 2016, p.7). This is by no means a singular position; Sebastian Kurz, while still minister of foreign affairs stated that "it is crucial that we do not surrender to Turkey or become dependent on them. Europe has to protect its own borders" (Siebenhaar and Stehle 2016). This notwithstanding, the Austrian government stated its commitment to the refugee deal.

In the Austrian presidential elections in December 2016, the FPÖ candidate, Norbert Hofer gained a plurality of votes, coming in first with about $35 \%$ of the votes in the first round (Vieten and Poynting 2016, p. 534). During the presidential election campaign, he promised to take Austria out of the EU if Turkey is allowed to join (Agerholm 2016). He was narrowly defeated in the run-up, which was in part influenced by the public reaction to the refugee (reception) crisis; the one to win the presidential race was Alexander Van der Bellen, from the Greens. For the first time Austria witnessed a second round of the presidential elections, and now a president coming from outside the two dominating political forces, the Social Democrats and the Christian Democrats (Politico 2016).

In 2017 parliamentary elections, the Christian Democrats, rebranded as the new People's Party (Die neue Volkspartei) won $31.5 \%$ of the votes under the leadership of Sebastian Kurz. It formed a coalition with FPÖ, which aimed to limit immigration; to decrease welfare benefits to non-Austrians; and to prevent the influence of political Islam (New York Times 2016). Thus, Austria became one of the few West European countries to have a right-wing populist party in a governing coalition in power. As such, it seems Austria's policy towards Turkey's EU membership bid would remain skeptical for the foreseeable future. In addition, Turkish immigrants and Turkey's accession process may continue to be used in political confrontations as a culturally polarizing issue particularly before elections, by both center-right and especially by right-wing populist parties. 


\subsubsection{Case 3: Instrumentalization of Turkey and Turkish Immigrants in German Politics and the Rise of AfD}

Germany, as the main destination country for many Syrians coming through Turkey and Greece, has experienced first-hand the effect of the refugee (reception) crisis. Consequently, one of the main themes in German politics, especially in recent years, has been immigration. Turkish immigrants are the largest minority group in Germany. Germany signed a bilateral recruitment agreement with Turkey on 30 October 1961 because of the shortages in its labor market. Although the recruitment of guest workers was initially intended to be temporary, Turkish immigrants have become a permanent component of German society. However, despite a long history of immigration, Germany insisted on not being a country of immigration (Senay 2017).

The recent refugee (reception) crisis has been one of the most important issues to influence German politics recently, and it has revealed deep divisions within German society. Chancellor Angela Merkel stated at the end of August 2015 that there were no limits to the number of refugees Germany would accept; her famous phrase was "we can handle this". Moreover, Germany was the pioneering country, which pushed for the solidarity principle across the EU for sharing the burden of accommodating all the incoming refugees. However, this system would not function because of the resistance of several countries. On 19 September 2016, Merkel admitted that errors had been made with regard to the refugee policy. In the aftermath of the crisis, Germany made significant investments for integrating immigrants in German society, and in May 2016 the government agreed on a new integration law.

At the Congress of the Bavarian-based Christian Social Union (ChristlichSoziale Union, CSU) in September 2016, there was a demand for a clear change of "Berlin's asylum politics". There were requests for introducing an upper limit of 200,000 asylum seekers per year; the abolition of dual citizenship (which had been introduced in order to better integrate Turkish immigrants); and the immediate deportation of immigrants with rejected asylum applications. In addition, a permanent federal ban on the burka, and the development of a general law to limit immigration were listed among the main requests for further cooperation between CSU and Merkel's Christian Democratic Union (Christlich Demokratische Union Deutschlands, CDU) for the period between October 2016 up to fall 2017, when federal elections were held.

The radical right National Democratic Party (Nationaldemokratische Partei Deutschlands, NPD) had a marginal influence contained to the sub-federal level, while the AfD, which was established in 2013, had a surprising ascension into German politics in the aftermath of the economic and refugee (reception) crises, even entering the federal parliament after the 2017 elections. AfD was founded as a single issue-party focused on opposing the Euro and the Eurozone bailouts, but in 2015, after a split, the party's new leader transformed it into an anti-immigration and anti-Islam party (Dennison and Pardijs 2016, p.17). AfD exhibits 
ethnocentrism, xenophobia, and nativism, which is a combination of xenophobia and ethnic nationalism and it claims that the "homogeneous nation" is under threat (Schelter et al. 2016, pp. 440-441). AfD also shares some similar concerns against immigration with PEGIDA (Patriotische Europäer Gegen Islamisierung des Abendlandes, see Önnerfors, Chap. 9 in this volume), which would gather popular support, especially in Dresden, in late 2014 and early 2015 as a radical right and xenophobic social movement. While German mainstream parties condemned PEGIDA for its xenophobia and Islamophobia, AfD views PEGIDA more favorably. AfD's main "others" are the Muslim refugees and immigrants. Illustratively, during the AfD campaign for the Berlin state parliament, campaign placards were printed in both Russian and Polish, besides German. However, there were no posters in Turkish, despite that Turks are the largest minority group in Berlin (Zeller 2016). Some of its leading politicians, such as Alexander Gauland, expressed racist opinions about Germans of foreign origin (Benedikter and Karolewski 2016, pp. 425-426). AfD's slogan is "Asylum Requires Borders - Red Card for Merkel"; it perceives the refugee (reception) crisis and the subsequent integration of immigrants and refugees as the biggest threat facing Europe.

In the aftermath of economic and financial crises of the Eurozone, which were followed shortly by the European refugee (reception) crisis, Germany's leadership role within the EU has become stronger, and Germany wields crucial influence in defining strategic relations with Turkey (Turhan 2016, p. 29). In this context, AfD opposes Turkey's EU membership bid because of ethno-cultural differences (Grimm 2015, p. 273). The AfD policy towards Turkey's EU membership was made explicit in the party program for the 2014 EU parliamentary elections. It advocated, "first consolidation, then expansion: EU accession negotiations with Turkey are to be stopped. The accession of additional countries requires their fulfillment of all entry criteria". In the field of immigration and asylum policy, it was emphasized that: "Immigration to gain free access to the German social systems must be prevented [...]" (AfD Party Program 2014). More recently, the AfD's policy platform reads "Islam does not belong to Germany" and calls for a ban on the construction of mosques (New York Times 2016), declaring Islam incompatible with German culture (Sky News 2017).

The attitude towards Turkish immigrants seems to be ambivalent (Senay 2017). On the one hand, Wolfgang Kaschuba, the director of the Berlin Institute for Integration and Migration Research, argues "the new [Syrian] migrants occupy the outermost position of the German social order while those with an immigrant background, who have already been in Germany for a long time move to the center" (Kaschuba in Senay 2017). As a result, the recent refugee (reception) crisis has contributed to intensified exchanges between the Turkish minority and the German majority. Moreover, it has increased the need of German authorities to cooperate with the Turkish minority on this matter. On the other hand, this "crisis" has led to rising anti-immigrant sentiments and discourses, which have negative implications for the German Turks as well. The Cologne sexual assaults on New Year's Eve in December 2015 (see also Edenborg, Chap. 7 in this volume) were particularly potent in triggering a highly controversial debate about refugees, as well as Islamic 
culture more broadly, with wider negative implications for Germany's Muslim population, including the Turkish minority (Senay 2017).

Turkish immigrants and Turkey's EU membership bid have been a popular debate in German domestic politics for many years, in particular due to the discourse and politics of CDU and CSU. Following the same path, the AfD instrumentalized problems associated with refugees and emphasized the cultural security theme in its discourse with regard to the incoming refugees, the integration of the Turkish minority in Germany, and Turkey's EU membership. This approach has proven successful even in ensuring AfD's entrance into the German federal parliament.

\subsection{Conclusions}

Socio-economic turbulences like financial and economic crises, and forced migration create a favorable environment for the rise of right-wing populist parties (Dudasova 2016, p. 327). In this context, adopting a stance against Turkey's EU membership, and the presence of Turkish immigrants in Europe can be observed as one of the remarkable arguments of these parties to strengthen their roles by galvanizing support. This notwithstanding, many right-wing populist parties do not have yet a significant presence in their respective parliaments. However, they may influence mainstream parties' discourses and policies, particularly related to politics of migration (Akkerman 2018). For instance, UKIP won only one seat in the May 2015 elections but its populist rhetoric has nonetheless triggered anti-immigrant and anti-EU sentiments in the UK, which eventually determined the Conservatives to call for the Brexit referendum (Inglehart and Norris 2016, p. 6). Therefore, the discourse of these parties against Turkey and Turkish immigrants may bring long lasting side effects beyond mobilizing their voters at election time or for referendums.

As this chapter unveiled, right-wing populist actors in Europe resort to the use of Turkish migrants and Turkey (in particular, its EU membership process) as an "othering" element and culturally polarizing issue within European societies, by employing the theme of cultural security. In the case of Germany, Turkey's EU membership process and the existence of Turkish minority in the country have been frequently used in domestic politics by CDU for many years. However, after the financial crisis and the refugee (reception) crisis, AfD started to employ these elements more strongly as a culturally polarizing issue and promoted them as part of cultural security threats, which contributed to its rise and entrance to German federal parliament. In fact, AfD became the first right-wing populist party with a radical agenda to enter the federal parliament after the World War II. Similarly, these elements have been intensively used also in Austrian right-wing politics for several years. FPÖ, which became the junior partner in the coalition government after 2017, has been using them more strongly as a culturally polarizing issue in recent years, especially with the rise of refugee (reception) crisis-based populism in Europe. 
The Brexit referendum in the UK is a distinctive case. It shows that political actors may combine the cultural security theme with other issues, such as criminalization and alleged mass migration, to strengthen their discourse and to mobilize more voters. The instrumentalization of Turks is not unexpected in German and Austrian right-wing politics since there have been already high levels of skepticism towards Turkey's EU membership in these countries and they have significant Turkish communities too. However, Vote Leave campaign and the Brexit process overall showed that right-wing populist discourse may instrumentalize Turkey and Turks as a cultural security issue even in a country, which is relatively more supportive of Turkey's EU membership and which does not have a remarkable Turkish immigrant community experience. Meanwhile, the resurgence of negative discourse on immigrants and refugees, as observed in the cases of Austria and Germany, maintain and even strengthen the cultural boundaries separating the Turkish immigrants from their host European societies. Such a stance may prove to have a negative impact on the long run, not only by slowing down and endangering the integration process of Turkish immigrants but also by preventing social cohesion in European societies.

\section{References}

Agerholm, H. (2016). Austrian far-right presidential hopeful Norbert Hofer calls for burqa ban. Independent. http://www.independent.co.uk/news/world/europe/burqa-ban-austria-presidential-poll-far-right-turkey-eu-norbert-hofer-fpo-a7191351.html. Accessed 5 Dec 2018.

Ajanovic, E., Mayer, S., \& Sauer, B. (2016). Spaces of right-wing populism and anti-Muslim racism in Austria. Politologický časopis-Czech Journal of Political Science, 23(2), 131-148.

Akkerman, T. (2018). The impact of populist radical-right parties on immigration policy agendas: A look at the Netherlands. Washington, DC: Migration Policy Institute.

Bail, C. (2008). The configuration of symbolic boundaries against immigrants in Europe. American Sociological Review., 73(37), 185-203.

BBC. (2016, May 24). EU referendum: Row over Turkey's membership bid escalates. http://www. bbc.com/news/uk-politics-eu-referendum-36353013. Accessed 25 Sep 2017.

Benedikter, R., \& Karolewski, I. P. (2016). "We can handle this" - how the refugee and migration crisis is changing the German political landscape. Israel Journal of Foreign Affairs, 10(3), 423-435.

Berezin, M. (2009). Illiberal politics in neoliberal times: Culture, security and populism in the new Europe (p. 304). Cambridge: Cambridge University Press.

Betz, H. (2001). Exclusionary populism in Austria, Italy and Switzerland. International Journal, 56(3), 393-420.

Boffey, D., \& Helm, T. (2016). Vote Leave embroiled in race row over Turkey security threat claims. The Guardian. https://www.theguardian.com/politics/2016/may/21/vote-leave-prejudice-turkey-eu-security-threat. Accessed 22 May 2018.

Bozdaglioglu, Y. (2004). Turkish foreign policy and Turkish identity: A constructivist approach. Routledge.

Dennison, S., \& Pardijs, D. (2016). The world according to Europe's insurgent parties: Putin, migration and people power. European Council on Foreign Relations (27 June 2016), 1-40.

Dudasova, M. (2016). Political consequences of the refugee crisis: The case of Germany. Ekonomické Rozhlady-Economic Review, 45(3), 312-330. 
European Commission (2016). What do citizens' opinions and perceptions mean for EU enlargement? European Policy Brief.

Gavenda, M. (2017). Austria. FEUTURE EU28 country report (EU Horizon 2020 project on the future of EU-Turkey relations). https://www.feuture.uni-koeln.de/sites/feuture/pdf/ Austria_28_Country_Report.pdf. Accessed 15 Feb 2018.

Gerhards, J., \& Hans, S. (2011). Why not Turkey? Attitudes towards Turkish membership in the EU among citizens in 27 European countries. Journal of Common Market Studies, 49(4), 741-766.

Grimm, R. (2015). The rise of the German Eurosceptic party Alternative für Deutshcland, between ordoliberal critique and popular anxiety. International Political Science Review, 36(3), 264-278.

Guild, E. (2005). Cultural and identity security. In In international migration and security (pp. 119-130). Routledge.

Hellström, A. (2016). Trust us: Reproducing the nation and the Scandinavian nationalist populist parties. New York: Berghahn.

İçduygu, A. (2011). Europe, Turkey, and International Migration: An Uneasy Negotiation. Presentation at the Migration Working Group, European University Institute, 26.

Inglehart, R. F., \& Norris, P. (2016). Trump, Brexit and the rise of populism: Economic havenots and cultural backlash. Harvard Kennedy School Faculty Research Working Paper Series. https://research.hks.harvard.edu/publications/getFile.aspx?Id=1401. Accessed 15 Feb 2018.

Kaya, A. (2009). Islam, migration and integration: The age of securitization. London: Palgrave Macmillan.

Kirişci, K. (2003). The question of asylum and illegal migration in European Union-Turkish relations. Turkish Studies, 4(1), 79-106.

Küçükcan, T. (1999). Politics of ethnicity, identity and religion: Turkish Muslims in Britain. Ashgate Pub Ltd..

Lister, S. (2016). EU referendum: Vote Leave faces criticism over Turkey 'criminals' claim. Independent. http://www.independent.co.uk/news/uk/politics/eu-referendum-vote-leave-facescriticism-over-turkey-criminals-claim-a7041876.html. Accessed 21 May 2018.

Mandac1, N., \& Özerim, G. (2013). Uluslararası Göçlerin Bir Güvenlik Konusuna Dö-nüşümü: Avrupa'da Radikal Sağ Partiler ve Göçün Güvenlikleștirilmesi. Uluslararası İlişkiler, 10(39), $105-130$.

Mason, R. (2016). Ukip accused of scaremongering over ad denouncing Turkey. The Guardian. https://www.theguardian.com/politics/2016/feb/04/ukip-accused-scaremongering-advertdenouncing-turkey-islamophobia. Accessed 4 Feb 2018.

Müftüler-Bac, M. (1998). The never-ending story: Turkey and the European Union. Middle Eastern Studies, 34(4), 240-258.

Neumann, I. (1998). Uses of the other: "The east" in European Identity Formation (Borderlines series). Minneapolis: University of Minnesota Press.

New York Times. (2016, May 22). How far is Europe swinging to the right? https://www.nytimes. com/interactive/2016/05/22/world/europe/europe-right-wing-austria-hungary.html. Accessed 23 Oct 2017.

Norocel, O. C. (2017). Åkesson at Almedalen: Intersectional tensions and normalization of populist radical right discourse in Sweden. NORA: Nordic Journal of Feminist and Gender Research, 25(2), 91-106.

Öner, S. (2011). Turkey and the European Union: The question of European identity. Lanham: Lexington Pub.

Party Programme of the AfD for the Election to the EP. (2014, May 25). Courage to stand up for Germany. For European Diversity (English summary).

Politico (2016, May 19). Austria's right-wing insurgency. www.politico.eu/article/austria-political-upheaval-not-just-flirting-with-far-right-werner-faymann-norbert-hofer-fpo/. Accessed 14 Sept 2018.

Schelter, S., Biessmann, F., et al. (2016). Structural patterns in the rise of Germany's new right on Facebook. IEEE 16th international conference on data mining workshops. 
Senay, B. (2017). Instrumentalising the influx of refugees for boundary-change? The Turkish community in the pursuit of social acceptance in Germany. Sussex Centre for Migration Research Working paper, 91, 1-25.

Siebenhaar, H.P., \& Stehle, A. (2016). Austria, the thorn in Merkel's side. Handelsblatt Global. https://global.handelsblatt.com/politics/austria-the-thorn-in-merkels-side-469706. Accessed 14 Mar 2018.

Sky News. (2017). German election 2017: Will anti-Islam AfD win their first seats? http:// news.sky.com/story/german-election-2017-anti-islam-afd-to-win-their-first-seats-11020635. Accessed 15 Feb 2018.

Sirkeci, I., \& Esipova, N. (2013). Turkish migration in Europe and desire to migrate to and from Turkey. Border Crossing, 3(1), 1-13.

Tardif, J. (2002). Intercultural dialogues and cultural security, Globalpolicy.org. https://www.globalpolicy.org/component/content/article/162/27588.html. Accessed 3 Mar 2018.

Turhan, E. (2016). Europe's crises, Germany's leadership and Turkey's EU accession process, CESifo Forum.

Turkish Ministry of Foreign Affairs (2018). Turkish citizens living abroad. http://www.mfa.gov.tr/ the-expatriate-turkish-citizens.en.mfa. Accessed 3 Mar 2018.

Vieten, U. M., \& Poynting, S. (2016). Contemporary far-right racist populism in Europe. Journal of Intercultural Studies, 37(6), 533-540.

Wets, J. (2006). The Turkish Community in Austria and Belgium: The challenge of integration. Turkish Studies, 7(1), 85-100.

Wheeler, C., \& Giannangeli, M. (2016). Brexit game changer: A third of Britons say they will vote LEAVE if Turkey joins EU". Express. https://www.express.co.uk/news/world/652142/thirdBrits-leave-EU-Europe-Turkey-joins-immigration-human-rights-concerns-Erdogan-press. Accessed 14 Mar 2016.

Williams, H. (2006). The impact of radical right wing parties in west European democracies. Basingstoke: Palgrave Macmillan.

Yabanc1, B. (2016). The future of EU-Turkey relations: Between mutual distrust and interdependency. FEUTURE Online Papers, 1, 1-36.

Yilmaz, H. (2007). Turkish identity on the road to the EU: Basic elements of French and German oppositional discourses. Journal of Southern Europe and the Balkans, 9(3), 293-305.

Zeller, M. (2016). The Last Domino: Germany and the alternative für Deutschland. ERA Institute. www.erainstitute.org/the-last-domino-germany-and-the-alternative-fur-deutschland/. Accessed 29 Nov 2018.

Open Access This chapter is licensed under the terms of the Creative Commons Attribution 4.0 International License (http://creativecommons.org/licenses/by/4.0/), which permits use, sharing, adaptation, distribution and reproduction in any medium or format, as long as you give appropriate credit to the original author(s) and the source, provide a link to the Creative Commons license and indicate if changes were made.

The images or other third party material in this chapter are included in the chapter's Creative Commons license, unless indicated otherwise in a credit line to the material. If material is not included in the chapter's Creative Commons license and your intended use is not permitted by statutory regulation or exceeds the permitted use, you will need to obtain permission directly from the copyright holder.

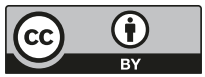

